\title{
Adaptive Reasoning Based on Microsoft Mathematics
}

\author{
Wati Susilawati ${ }^{1}$, Tika Karlina Rachmawati ${ }^{2}$, Ida Nuraida ${ }^{3}$ \\ 1,2,3Education and Teacher Training, Universitas Islam Negeri Sunan Gunung Djati, Indonesia \\ wati85@uinsgd.ac.id
}

\begin{abstract}
Article History:

Received : 20-01-2021

Revised : 27-03-2021

Accepted : 30-03-2021

Online : 17-04-2021

\section{Keywords:}

Adaptive reasoning; Mathematics learning;

Microsoft mathematics.

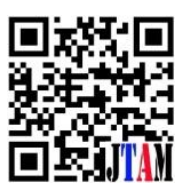

The demands of professional teachers to design technology-assisted learning that can facilitate all students to develop their potential. the fact that the quality of students' adaptive reasoning in solving math problems is still low which has an impact on other mathematical competencies. The purpose of this study was to determine the differences in the improvement of adaptive reasoning abilities between students who have implemented Search Solving Create and Share learning assisted with Microsoft Mathematics and conventional learning. The method used is quasi-experimental with the non-equivalent pre-test and post-test control group design. Through the Simple Random Sampling technique, two classes were selected, namely class X1 and X2 one of the SMA in Bandung Indonesia. Test instrument: story questions about adaptive reasoning abilities. Analysis using independent T-test data. Result: There is a difference in the improvement in adaptive reasoning abilities between students who using search-solve-createshare learning assisted by Microsoft mathematics compared to conventional learning. Students' difficulties in solving story problems with adaptive reasoning abilities can be minimized by getting used to solving non-routine story problems. Learning search-solve-create-share assisted by Microsoft mathematics accustoms students to convey assumptions, provide reasons for answers, draw conclusions from statements, and students can find patterns of various mathematical problems through multi-interactive media.
\end{abstract}




\section{A. INTRODUCTION}

Adaptive reasoning ability is one of mathematics learning purposes which is written in Content Standard. Adaptive reasoning is not only covering deductive reasoning, which only took conclusion based by formal proof deductively, but it also covers inductive and intuitive reasoning by taking conclusion based on pattern, analogy, and metaphor. Adaptive reasoning is related to students' logical thinking ability concerning mathematical concepts (Aaron \& Herbst, 2015). (Yanti et al., 2020) revealed that adaptive reasoning is related to students' logical thinking ability to provide various alternative solutions according to mathematical problem situations. This shows that adaptive reasoning is important to be mastered by the student to support learning ability.

According to (Wibowo, 2016) NCTM standard about adaptive reasoning is achieved by (1) directing mathematics problem, (2) building student's experience and knowledge, (3) developing mathematics thinking skill that convincing about the validity of a certain representation, making a conjecture, solving the problem or making answer from a student, (4) involving student's intellectual consisting of directing question and task that involved student, and challenged student, (5) developing student knowledge and mathematics skill, (6) stimulating student to make the connection and to develop a framework which is coherent for mathematics ideas, (7) useful to problem formulation, problem solution, and mathematics reasoning, and (8) promoting the development of all students ability to do mathematics works. According to (Muin et al., 2018) there are indicators for adaptive reasoning, which is (1) directing conjecture; (2) giving a reason for the answer; (3) concluding a statement; (4) checking the validity of an argument; and (5) discovering mathematics problem pattern. Yet, in this research, the five indicators have been modified into four indicators, which are (1) directing conjectures (2) checking the validity of the argument (3) providing reasons for the answers given; (4) describe the conclusion of a statement. So that adaptive reasoning can be carried out through innovative and contextual learning.

Empirically, the cold fact has shown that the level of student adaptive reasoning abilities is still low. This is based on a study conducted in a high school in Bandung, it was found that more than $50 \%$ of students have a low level of adaptive reasoning ability (Wati Susilawati \& Dewi, 2019). Likewise with the results of research (Yusrawati Syahkubat, Siti M Amin, 2017) that student attitudes during learning and mathematical logical thinking abilities are still low. Research conducted by (Setiawan et al., 2018) shown that a student's adaptive reasoning ability is not satisfying yet because the obtained score of a student's adaptive reasoning ability is still below the minimum completion criterion. As a result, many students fail to manifest extraordinary performance in math subjects (Fluck \& Dowden, 2013). The low level of student's adaptive reasoning, allows mathematics learning only demands a student's ability, but not considering student's potential. Nonoptimal learning process, a teacher not involves the student in the learning process even there was no interaction between a student with student and student with teacher, a student is not doing exploration, discovering properties, arranging and testing conjecture, but the student only receive what has been given or taught. Now the educational process seems to support rote learning (Rofiki et al., 2017) just looking for the correct answer without finding another solution. As a result, most students lack adaptive reasoning skills. According to research (Darwani et al., 2020) that students are not able to understand non-routine problems in solving their adaptive reasoning abilities and they 
struggle to use their reasoning power and consequently, they cannot formulate, present and solve problems efficiently, precisely, and logically. Even though the adaptive reasoning process is one of the goals of learning mathematics since students enter junior high school (Ansari et al., 2020; Dawkins \& Roh, 2016). The lack of student's adaptive reasoning aspect is also caused by the mathematics learning model that is not facilitating student to learn actively and not stimulates the student to use reasoning (Yanti et al., 2020) With the complexity of these problems, a learning model is needed that can generate students' adaptive reasoning skills.

There is a lot of learning model alternative that can facilitate mathematics reasoning ability development, one of it is Search-Solve-Create-and Share (SSCS) learning model. This model covers four phases, which is: First, the Search phase aims to identify the problem. Second, the Solve phase aims to plan a problem solution, a student looks for an alternative answer that is possible to solve the problem. Third, the Create phase aims to execute varied problem solving, a student writes an answer idea which is assumed as true that obtained from the Solve phase. And the least, the Share phase aims to socialize the problem solving, the student discusses the obtained his/her obtained answer to other groups to be evaluated together (Mursyidah et al., 2019). Several researchers have researched the SSCS learning model, including (Milama et al., 2017) that SSCS can improve students' mathematical critical thinking skills. (Delta Aringga Rakhmi, Kartono, 2018) revealed that learning with the SSCS model had a significant effect in improving students' dispositional abilities and understanding of mathematical concepts. (Kurniawati, L., Fatimah. B, 2014) that SSCS learning can improve students' logical thinking skills. (Diani et al., 2019) revealed that the SSCS cooperative learning model is an alternative to improving students' reflective thinking skills and mathematical problem-solving abilities.

We have to realize the importance of learning that potentially develops adaptive reasoning ability. It needs the effort to choose learning technology that completely able to stimulate interest and to be motivated in the learning process, that looks after uniqueness of a being, that can solve a problem is applying Search-Solve-Create-and Share learning assisted by Microsoft Mathematics software, that triggers student to plan learning media as concept formulation project. Microsoft Mathematics is software that has a symbolic computation system and works based on mathematics models. The Discovery result of (Mendezabal \& Tindowen, 2018) said that Microsoft Mathematics can improve student learning motivation. The research results (Oktaviyanthi \& Supriani, 2015a) show that the use of Microsoft Mathematics in teaching and learning increases students' conceptual understanding and procedural skills. The study results show (Angeles et al., 2015) that applying Microsoft Mathematics has a positive influence on educational technology in enriching students' mathematics learning and increasing student motivation to be more involved in classroom learning activities. According to research results (Wati Susilawati \& Suryadi, 2020), it is proven that multimedia-based mathematics learning is the most effective in improving the process and student learning outcomes.

Based on the consideration of some of these research results, the SSCS learning model has been widely researched but has never been applied with the help of Microsoft Mathematics to adaptive reasoning abilities. The purpose of this study is to analyze the differences in the improvement of adaptive reasoning skills between students who have implemented Search Solving Create and Share learning assisted by Microsoft Mathematics and conventional learning. And to analyze the difficulties of students in solving problems of adaptive reasoning ability. The method used is quasi-experimental. The random sampling technique cluster 
consists of an experimental class (SSCS assisted by Microsoft mathematics) and a control class (conventional).

\section{B. METHODS}

The quasi-experimental research method with the nonequivalent pre-test and post-test control group design sampling method is Probability Sampling, where each member of the population has the same chance to be selected, through the Simple Random Sampling technique, with the consideration that sampling from the population is carried out randomly without considering the strata in the population. In this study, all students in class X for the 2018/2019 academic year consisted of 10 parallel classes at one of the public high schools in Bandung. The samples were taken as many as two classes, namely class X 1 with 35 students (experimental class) and class X 2 was many as 34 students (control class). The sample selection of the two groups was with the consideration of seeing the difference in the increase in adequate reasoning abilities between the experimental group students who carried out SSCS learning assisted by Microsoft mathematics and the control class who carried out conventional learning. Before and after learning, the group was given a test. The test instrument is in the form of adaptive reasoning ability.

The research procedure consists of 1) planning, 2) executing, and 3) research solution. In the planning phase, doing the preliminary study to see the student's first adaptive reasoning. Continued by making the trial test problem, executing the trial test problem, and analysing the result. The last planning is making research instruments such as making the learning instrument learning, Student workspace, material, and questionnaire. Next is the executing phase. This phase is started by doing a pre-test to experiment and control class, before giving the treatment. After that, treatment is given to the two classes with each 4 learning meetings and ended by post test to see the significant improvement of student's adaptive reasoning skill after being given treatment. Last phase, which is analysing pre-test and post test data to see the significant improvement of student's adaptive reasoning skills of experiment and control class, by using an independent T-test. Through quasi-experimental research, students in classes that obtain learning in search-solve-create-and share assisted by Microsoft Mathematics are required to be actively involved in the learning process such as constructing their concepts, active in group discussions, and solving divergent problems. Whereas in conventional classes students tend to be passive in learning, there are only a few students who are actively involved in the learning process.

\section{RESULT AND DISCUSSION}

To find out the significance of the increase in adaptive reasoning ability between students who were treated with search-solve-create-and share learning assisted by Microsoft Mathematics and students with conventional learning, pre-test and post test data were used which were processed with the normalized gain formula. Recapitulation of pre-test and posttest statistical data can be seen in the following Table 1: 
Table 1. Data on the Pre-test and Post -test of Students' Adaptive Reasoning Ability

\begin{tabular}{cccccc}
\hline \multirow{2}{*}{ Pre-test } & Class & N & Minimum & Maximum & Average \\
\cline { 2 - 6 } & Experiment & 35 & 2 & 27 & 10,74 \\
\cline { 2 - 6 } Post-test & control & 34 & 7 & 23 & 16,44 \\
\cline { 2 - 6 } & Experiment & 35 & 42 & 91 & 71,11 \\
\cline { 2 - 6 } & control & 34 & 21 & 63 & 40,73 \\
\hline
\end{tabular}

The mean score for the pre-test and post-test in the experimental group was 10.74 and the mean score for the post-test was 71.11. This indicates that the increase in students' adaptive reasoning ability is higher than the pre-test and post test scores of the control group, namely 16.44 and 40.73 . To see the n-gain statistical data can be seen in table 2 .

Table 2. Descriptive Statistics of Students' Adaptive Reasoning N-Gain

\begin{tabular}{ccccccc}
\hline Class & $\mathbf{N}$ & Minimum & Maximum & Standard Deviation & $\boldsymbol{N}$-Gain & Criteria N-Gain \\
\hline Experiment & 35 & 0,38 & 0,88 & 0,130 & 0,675 & Medium \\
\hline Control & 34 & 0,01 & 0,52 & 0,127 & 0,290 & Low \\
\hline
\end{tabular}

The mean of the n-gain test for the adaptive reasoning ability of students who were given the search, solving, create, and share learning treatment based on Microsoft Mathematics was 0.675 better than students who were given the conventional learning treatment of 0.290 . To find out that there are differences in the improvement of adaptive reasoning abilities between students who are given the search, solve, create, and share learning treatment based on Microsoft Mathematics and students whose conventional learning can be statistically done with the t-test. Based on the normality and homogeneity tests of the n-gain data that have been carried out above, it is known that the n-gain data is normally distributed and the two classes have homogeneous variants so that further statistical analysis can be carried out using the independent t-test more clearly can be seen in Table 3.

Table 3. The Results of the Independent Sample T-Test for N-Gain Data

\begin{tabular}{ccccc}
\hline & \multicolumn{4}{c}{ t-test for Equality of Means } \\
\hline & $\mathrm{T}$ & $\mathrm{Df}$ & Sig. (2-tailed) & Mean Diference \\
\hline Equal variances assumed & 12.410 & 67 & .000 & .38513 \\
\hline \multicolumn{7}{c}{} \\
\hline
\end{tabular}

Table 3 shows The Sig (2-tailed) value is 0.000 which is meant for the two means of the same test. Whereas for the different tests the average of two Sig values. The value (2-tailed) should be divided into two, then compared with the value $\alpha=5 \%$. Because of the Sig. (2-tailed) is 0.000 , then after dividing the two it becomes 0.000 . It turns out that $0.000<0.05$, which means that $\mathrm{HO}$ is rejected. In another way, it can be concluded that there is a significant increase in the adaptive reasoning ability of students who do search-solve-create- and share learning with the help of Microsoft Mathematics better than students who learn conventional learning.

The SSCS learning model consists of four problem-solving steps, the sequence starting from problem investigation (searching), planning for troubleshooting, drafting problem solving (create), and finally communicating the solution obtained (sharing). The accuracy of selecting the SSCS cooperative learning model is an important component in efforts to improve students' 
adaptive reasoning abilities in the experimental class. This can happen because SSCS learning has different characteristics from conventional learning models. According to research (Lia \& Bunga, 2014) that search-solving-create- and share learning can improve mathematical logical thinking skills compared to conventional learning. The results of the study (Syafri et al., 2020) show that the mathematical problem solving abilities of students who are taught using the SSCS model are better than students who are taught using conventional learning models. The results of the study (Lestari et al., 2020) show that learning SSCS with a quality contextual approach can improve mathematical literacy and self-efficacy. The results of the study (Sukariasih et al., 2019) shows that the SSCS model can improve high school student learning outcomes compared to conventional learning The results of the study (Yasin et al., 2020) show that SSCS learning has effectiveness which is relatively high so that it has an effect of $91.9 \%$ on the ability to think reflective and the ability to solve mathematical problems. Thus, effective SSCS learning can improve the ability to explore, predict, and reason logically, solve non-routine problems, communicate connect ideas in mathematics and other intellectual activities.

Adaptive reasoning has increased significantly in the experimental class, according to the results of the study (Lestari et al., 2020) students can think logically when choosing the appropriate concept, procedural material, and applying formulas. The results of the study (Rustana \& Sumantri, 2019) show that adaptive reasoning can affect conceptual understanding and scientific literacy. The results of the study (Mahendra et al., 2017) show that students' adaptive reasoning has increased through reform learning rather than conventional learning. The findings (Fikriya et al., 2018) show that students' adaptive reasoning abilities experience a higher increase through creative problem solving learning compared to conventional learning. Thus, students' adaptive reasoning abilities improve better after learning to seek, solve, be creative, because students are required to be actively involved in composing concepts independently, sharing ideas in group discussions.

The quality of learning mathematics in the experimental class is more enthusiastic with the help of Microsoft math software, which makes it easier for students to better understand math content and interact with computers, which is not found in conventional learning. Microsoft Mathematics is freeware created by Microsoft Corporation to help students ensure the correctness of problem-solving results faster and easier independently. Its features provide students with step-by-step solutions to various math problems, very simple operations without basic knowledge of programming languages such as Matlab, maple, and Cabri. Its existence helps students solve problems related to several concepts, pacts, procedures, and problemsolving methods in problem situations(Dermawan et al., 2019). This follows the results (Purwanti \& Pustari, 2013) which state that Microsoft Mathematics can increase students' creativity to think of many unique ideas to solve problems. Based on the results of research (Jean, M, N., Mendezabal, 2018) that learning mathematics with the help of Microsoft Mathematics can improve students' conceptual understanding and procedural skills in solving problems.

This application strongly supports learning with a constructivist approach, where students are directed to find mathematical concepts based on their initial understanding (Jang \& Tsai, 2012). The results of student work can be saved in the form of worksheets so that they can be opened again. This application is very suitable and relatively easy as an alternative medium in supporting mathematics learning that is more effective and meaningful. The use of Microsoft 
Mathematics in learning mathematics will be able to increase creativity because it allows students to manipulate themselves in solving math problems as desired. Following the findings (Oktaviyanthi \& Supriani, 2015b) that students who carry out mathematics learning with the help of Microsoft Mathematics show better learning outcomes and have a positive impact on high self-confidence in solving math problems. According to research(Purwanti \& Pustari, 2013) it was found that the learning achievement of students who use Microsoft Mathematics is higher than students who are taught using traditional teaching methods. The Microsoft Mathematics screen display is as follows:

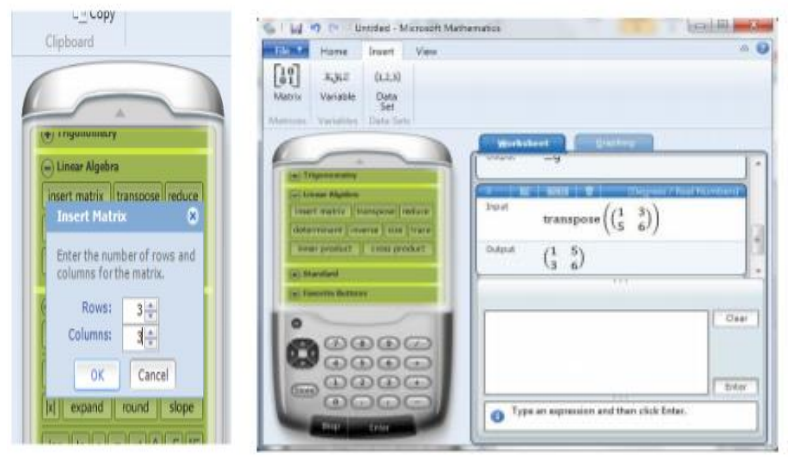

Figure 1. Screen Display of Microsoft Mathematics.

Based on the results of the analysis of students' problems in solving adaptive reasoning problems, there are some students who have not been optimal in solving adaptive reasoning ability problems, because they are not used to solving non-routine math problems that require high-order thinking skills. Students must develop their thinking because every knowledge or skill can only be obtained or mastered, if students are actively involved in constructing knowledge or skills in their thinking (Lestari et al., 2020). However, all problems can be minimized by getting students to practice solving non-routine problems. According to research results (Muin et al., 2018); (Darwani et al., 2020) to get used to the practice of mathematical adaptive reasoning problems, students must be facilitated in the form of questions that require creativity in various alternative solutions in developing higher-order thinking skills in accordance with the given problem situation. Thus (W. Susilawati, 2020) states that students can learn well through self-habituation, meaning that students must be accustomed to working on non-routine questions to get better results. So that learning SSCS with the help of Microsoft mathematics can improve the quality of students' adaptive reasoning abilities.

\section{CONCLUSION AND SUGGESTIONS}

Improved adaptive reasoning skills among students who have implemented Search, Solve, Create, and Share learning with the help of Microsoft Mathematics are better than students who have implemented conventional learning. The difficulty of some students in solving adaptive reasoning problems is because they are not used to solving non-routine math story problems with high-order thinking skills. All problems can be minimized by getting students accustomed to solving non-routine adaptive reasoning problems with higher order thinking skills. Suggestions for future researchers to more specifically analyze adaptive reasoning abilities from their intuitive-inductive and intuitive-deductive aspects. For the mathematics learning process, it will be more effective to integrate contemporary learning models using other 
software applications to ensure the proving results of problem solving performed by students procedurally.

\section{ACKNOWLEDGEMENT}

The authors acknowledge special to the Mathematics Education Study Program, Tarbiyah faculty, and Teacher Training and the Sunan Gunung Djati Bandung State Islamic University research institute the financial support.

\section{REFERENCES}

Aaron, W. R., \& Herbst, P. G. (2015). Teachers' perceptions of students' mathematical work while making conjectures: an examination of teacher discussions of an animated geometry classroom scenario. International Journal of STEM Education. https://doi.org/10.1186/s40594-015-0021-0

Angeles, M. R., Fajardo, A. C., \& Tanguilig, B. T. (2015). E-math version 2.0, a learning management system as a math reviewer tool for engineering students in the Philippines. International Journal of Engineering and Technical Research.

Ansari, B. I., Taufiq, T., \& Saminan, S. (2020). The use of creative problem solving model to develop students' adaptive reasoning ability: Inductive, deductive, and intuitive. International Journal on Teaching and Learning Mathematics, 3(1), 23-36. https://doi.org/10.18860/ijtlm.v3i1.9439

Darwani, Zubainur, C. M., \& Saminan. (2020). Adaptive reasoning and strategic competence through problem based learning model in middle school. Journal of Physics: Conference Series, 1460(1). https://doi.org/10.1088/1742-6596/1460/1/012019

Dawkins, P. C., \& Roh, K. H. (2016). Promoting metalinguistic and metamathematical reasoning in prooforiented Mmathematics courses: a method and a framework. International Journal of Research in Undergraduate Mathematics Education, 2(2), 197-222. https://doi.org/10.1007/

Delta Aringga Rakhmi, Kartono, Z. M. (2018). Constructtivism mathematics learning with search, solve, create, and share (sscs) model to improve mathematics disposition and student concept understanding of limit function materials of XI natural science class. Unnes Journal of Mathematics Education Research.

Dermawan, O., Defriyanto, D., Junaidah, J., Ayu, S. M., Busmayaril, B., Meisuri, M., \& Muhtari, M. J. (2019). Microsoft visual basic 6.0 software to develop mathematics teaching materials. Journal of Physics: Conference Series. https://doi.org/10.1088/1742-6596/1155/1/012090

Diani, R., Herliantari, H., Irwandani, I., Saregar, A., \& Umam, R. (2019). Search, solve, create, and share (sscs) learning model: the impact on the students' creative problem-solving ability on the concept of substance pressure. Jurnal Penelitian Fisika Dan Aplikasinya (JPFA). https://doi.org/10.26740/jpfa.v9n1.p65-77

Fikriya, A., Waluya, S. B., \& Sunarmi, S. (2018). The analysis of adaptive reasoning ability reviewed from students' confidence in ethnomathematic-based treffinger learning model. Unnes Journal of Mathematics Education, 7(2), 100-107.

Fluck, A., \& Dowden, T. (2013). On the cusp of change: Examining pre-service teachers' beliefs about ICT and envisioning the digital classroom of the future. Journal of Computer Assisted Learning. https://doi.org/10.1111/j.1365-2729.2011.00464.x

Jang, S. J., \& Tsai, M. F. (2012). Exploring the TPACK of Taiwanese elementary mathematics and science teachers with respect to use of interactive whiteboards. Computers and Education. https://doi.org/10.1016/j.compedu.2012.02.003

Jean, M, N., Mendezabal, D. J. C. T. (2018). Improving students' attitude, conceptual understanding and procedural skills in differential calculus through microsoft mathematics. Journal of Technology and Science Education, 8(4), 385-397.

Kurniawati, L., Fatimah. B, S. (2014). Problem solving learning approach using search, solve, create and share (sscs) model and the student's mathematical logical thinking skills. Proceeding.

Lestari, D. I., Waluya, S. B., \& Mulyono. (2020). Mathematical literacy ability and self-efficacy students in search solve create and share (sscs) learning with contextual approaches. Unnes Journal of Mathematics Education Research, 9(2), 156-162.

Mahendra, R., Slamet, I., \& Budiyono. (2017). The effect of problem posing and problem solving with 
realistic mathematics education approach to the conceptual understanding and adaptive reasoning. AIP Conference Proceedings. https://doi.org/10.1063/1.5016659

Mendezabal, M. J. N., \& Tindowen, D. J. C. (2018). Improving students' attitude, conceptual understanding and procedural skills in differential Calculus through microsoft mathematics. Journal of Technology and Science Education. https://doi.org/10.3926/jotse.356

Milama, B., Bahriah, E. S., \& Mahmudah, A. (2017). The Effect of Search, Solve, Create, And Share (SSCS) Learning Model towards Student's Critical Thinking Skills. Jurnal Penelitian Dan Pembelajaran IPA. https://doi.org/10.30870/jppi.v3i2.2574

Muin, A., Hanifah, S. H., \& Diwidian, F. (2018). The effect of creative problem solving on students' mathematical adaptive reasoning. Journal of Physics: Conference Series. https://doi.org/10.1088/1742-6596/948/1/012001

Mursyidah, R., Muharrami, L. K., Rosidi, I., \& Hadi, W. P. (2019). Pengaruh model pembelajaran search, solve, create, and share (sscs) terhadap keterampilan generik sains peserta didik. Natural Science Education Reseach.

Oktaviyanthi, R., \& Supriani, Y. (2015a). Utilizing microsoft mathematics in teaching and learning calculus. Journal on Mathematics Education. https://doi.org/10.22342/jme.6.1.1902.63-76

Oktaviyanthi, R., \& Supriani, Y. (2015b). Utilizing microsoft mathematics in teaching and learning calculus. Indonesian Mathematical Society Journal on Mathematics Education, 6(1), 63-76.

Purwanti, D. E., \& Pustari, M. (2013). The comparison of using microsoft mathematics and traditional teaching on students' achievement-teaching mathematics in senior high school. Proceedings of the Global Summit of Education, Malaysia.

Rofiki, I., Nusantara, T., Subanji, S., \& Chandra, T. D. (2017). Reflective plausible reasoning in solving inequality problem. IOSR Journal of Research \& Method in Education (IOSRJRME), 07(01), 101-112. https://doi.org/10.9790/7388-070101101112

Rustana, C. E., \& Sumantri, M. F. (2019). The analysis of mathematical adaptive reasoning (pam) and scientific literacy on the 10th grade students' understanding of physics concepts. AIP Conference Proceedings, 2169. https://doi.org/10.1063/1.5132642

Setiawan, E. P. A., Setiawan, E. P. A., Siswono, T. Y. E., \& Ekawati, R. (2018). Implementation of problem posing learning on conceptual understanding and adaptive reasoning. https://doi.org/10.2991/icei-18.2018.104

Sukariasih, L., Ato, A. S., Fayanto, S., Nursalam, L. O., \& Sahara, L. (2019). Application of sscs model (search, solve, create and share) for improving learning outcomes: the subject of optic geometric. Journal of Physics: Conference Series, 1321(3). https://doi.org/10.1088/1742$6596 / 1321 / 3 / 032075$

Susilawati, W. (2020). Improving students' mathematical representation ability through challengebased learning with android applications. Journal of Physics: Conference Series. https://doi.org/10.1088/1742-6596/1467/1/012010

Susilawati, W., \& Dewi, K. (2019). Reasoning ability through challenge based learning kahoot. Jurnal Analisa. https://doi.org/10.15575/ja.v5i2.6666

Susilawati, W., \& Suryadi, D. (2020). The challenge-based learning to students' spatial mathematical ability. Journal of Physics: Conference Series. https://doi.org/10.1088/1742-6596/1613/1/012039

Syafri, M., Zulkarnain, Z., \& Maimunah, M. (2020). The effect of sscs learning model on the mathematical problem Solving ability of junior high school students, Kampar Regency. Journal of Educational Sciences, 4(2), 309. https://doi.org/10.31258/jes.4.2.p.309-317

Wibowo, T. (2016). Adaptive reasoning junior high school students in mathematics problem solving. Proceeding of 3rd International Conference on Research, Implementation and Education of Mathematics and Science.

Yanti, A. W., Sutini, \& Kurohman, T. (2020). Adaptive reasoning profile of students in solving mathematical problems viewed from field-dependent and field-independent cognitive style. AIP Conference Proceedings. https://doi.org/10.1063/5.0000699

Yasin, M., Fakhri, J., Siswadi, Faelasofi, R., Safi'i, A., Supriadi, N., Syazali, M., \& Wekke, I. S. (2020). The effect of sscs learning model on reflective thinking skills and problem solving ability. European Journal of Educational Research. https://doi.org/10.12973/eu-jer.9.2.743

Yusrawati Syahkubat, Siti M Amin, \& R. S. (2017). Learning device problem solving search, solve, create, and share on social arithmetic material. Proceeding. 